\title{
A Study about Foreign Direct Investment in Indonesia
}

\author{
R.DhanyaDr. S. Ramachandran, \\ Research ScholarDirector - Dept. of Management,Bharath University, Chennai, AMET University,Chennai
}

\begin{abstract}
Foreign Direct Investment (FDI) is "the word" gaining popularity more in recent times in India. There are various speculations which is surrounding it in India. FDI has played a vital role in the growth and development of some of Asian countries like China, Indonesia, and Philippines. This paper is basically to study about the influence of Foreign Direct Investment in Indonesia.
\end{abstract}

Keywords:FDI,Indonesia

\section{Introduction:}

Similar to India and China, Indonesia has a huge population (fourth largest in the world) with a large number of middle-income consumers and is considered to be an attractive retail market. Indonesians are known to have a healthy appetite for imported goods and this sector has seen rapid growth and modernisation.

\section{FDI In Indoneasia:}

With a large internal market, a growing middle class, abundant naturalresources and a strategic location within Southeast Asia, Indonesia hasnatural appeal to foreign investors. Nonetheless, the Asian crisis of 1997 1998 and the ensuing economic and political turmoil kept economicactivity, including investment, far below Indonesia's potential. Years ofreforms in a vast range of policy areas are now being rewarded: stablegrowth, enhanced investor confidence particularly among foreigninvestors, and a renewed rise in foreign directinvestment (FDI) inflows.

The Indonesian Government opened the Agriculture sector for foreign investments in 2010 by issuing a presidential decree wherein it stated that foreign investors can own up to $49 \%$ of food plantation business. By this move it expected to encourage cash inflow into one of its priority projects, the vast Merauke food estate in Papua in eastern Indonesia.

Similar to India, agriculture sector is a major contributor to the GDP of Indonesia and employs a large number of people. Historically, Indonesia's economy has relied on agriculture - small-scale farming, large scale plantations and fishing.

In early 2000s, Indonesian Government lifted a number of restrictions on foreign investment and participation in the retail sector. Since then, Indonesia saw rapid expansion in retail sector with the emergence of a large number of modern retail outlets - Supermarkets, Hypermarkets and mini-markets. Currently, Indonesia has a high proportion of modern retail outlets than in India (Indonesia's 37\% Vs. India's 4\%). Currently, modern retail is most visible in the densely populated cities like Jakarta, Surabaya and Bandung.

Although Indonesia is an archipelago where transportation of food and other goods is restricted and challenging, it has well developed cold storage system which is maintained by the foreign investors and local wholesalers alike.

Chart 1: Foreign Investments in various sectors

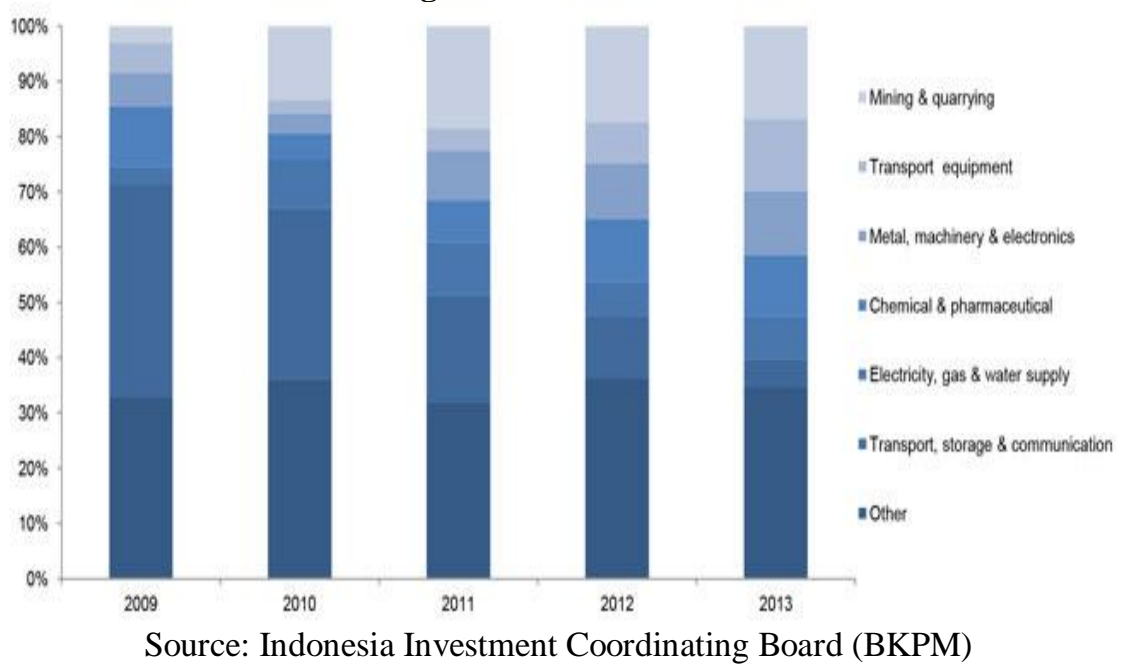


The above chart 1 explains the various sectors attracting the foreign investment. Mining and quarrying attracts the maximum followed by transportation, metal, machinery and electronics, Chemical and pharmaceutical, electricity, gas \& water supply, transportation, storage and communication and then finally others.

\section{FDI Inflows Till 2014:}

Foreign direct investment; net inflows (\% of GDP) in Indonesia was last measured at 2.27 in 2011, according to the World Bank. Foreign direct investment are the net inflows of investment to acquire a lasting management interest (10 percent or more of voting stock) in an enterprise operating in an economy other than that of the investor. It is the sum of equity capital, reinvestment of earnings, other long-term capital, and shortterm capital as shown in the balance of payments.

\section{Chart 2: FDI net inflows}

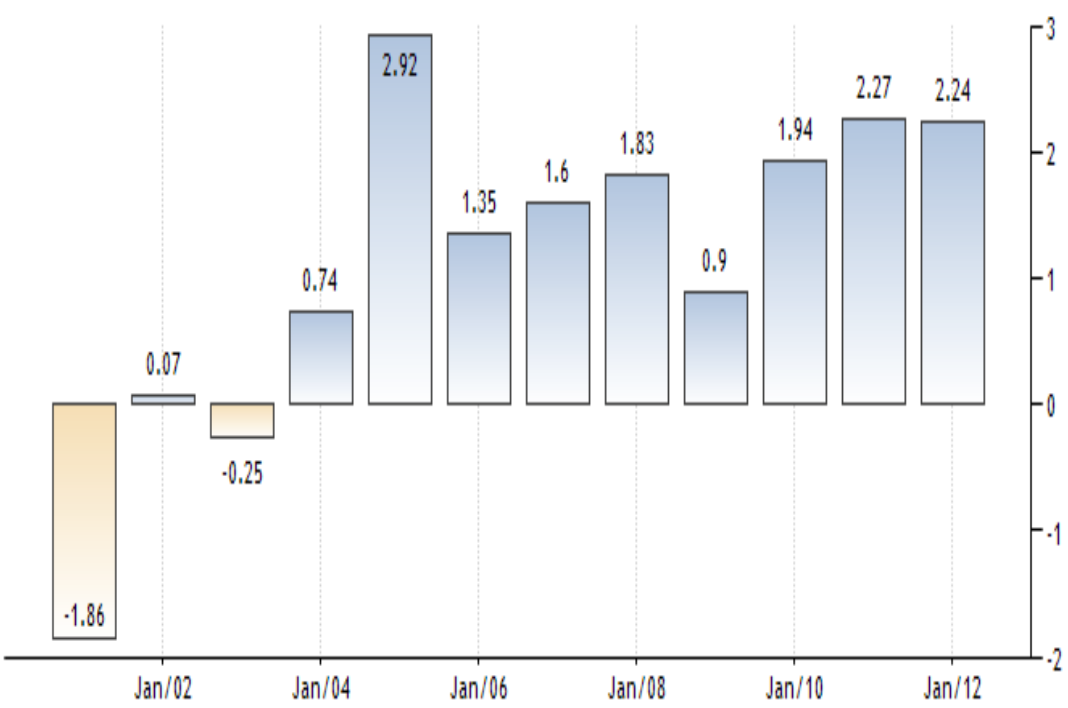

Source: www.tradingeconomics.com

The chart 2 shows the net inflows (new investment inflows less disinvestment) in the reporting economy from foreign investors, and is divided by GDP.

Table:1 World Bank Indicators - Indonesia - Balance of Payments (BoP)

\begin{tabular}{|l|l|l|l|}
\hline Particulars & 1990 & 2000 & 2010 \\
\hline Trade in services (\% of GDP) in Indonesia & 7.5 & 12.6 & 6.1 \\
\hline Communications; computer; etc. (\% of service imports; BoP) in Indonesia & 36.2 & 51.8 & \\
\hline Income payments (BoP; US dollar) in Indonesia & 5599000000.0 & 10900883886.1 & 226795898881.4 \\
\hline Imports of goods and services (BoP; US dollar) in Indonesia & 27511000000.0 & 56002459130.4 & 153536398207.8 \\
\hline Insurance and financial services (\% of service imports; BoP) in Indonesia & 3.9 & 2.1 & 6.2 \\
\hline Goods imports (BoP; US dollar) in Indonesia & 21455000000.0 & 40365376000.0 & 127447053592.3 \\
\hline Service imports (BoP; US dollar) in Indonesia & 6056000000.0 & 15637083130.4 & 26089344615.5 \\
\hline Royalty and license fees; payments (BoP; US dollar) in Indonesia & & & 1616459043.2 \\
\hline Imports of goods; services and income (BoP; US dollar) in Indonesia & 33110000000.0 & 66903343016.5 & 176215988089.2 \\
\hline Transport services (\% of service imports; BoP) in Indonesia & 46.2 & 25.7 & 33.2 \\
\hline
\end{tabular}

Source: www.tradingeconomics.com

The table 1 explains the balance of payments of Indonesia from 1990 to 2010. 
Chart 3: The major foreign investors in Indonesia

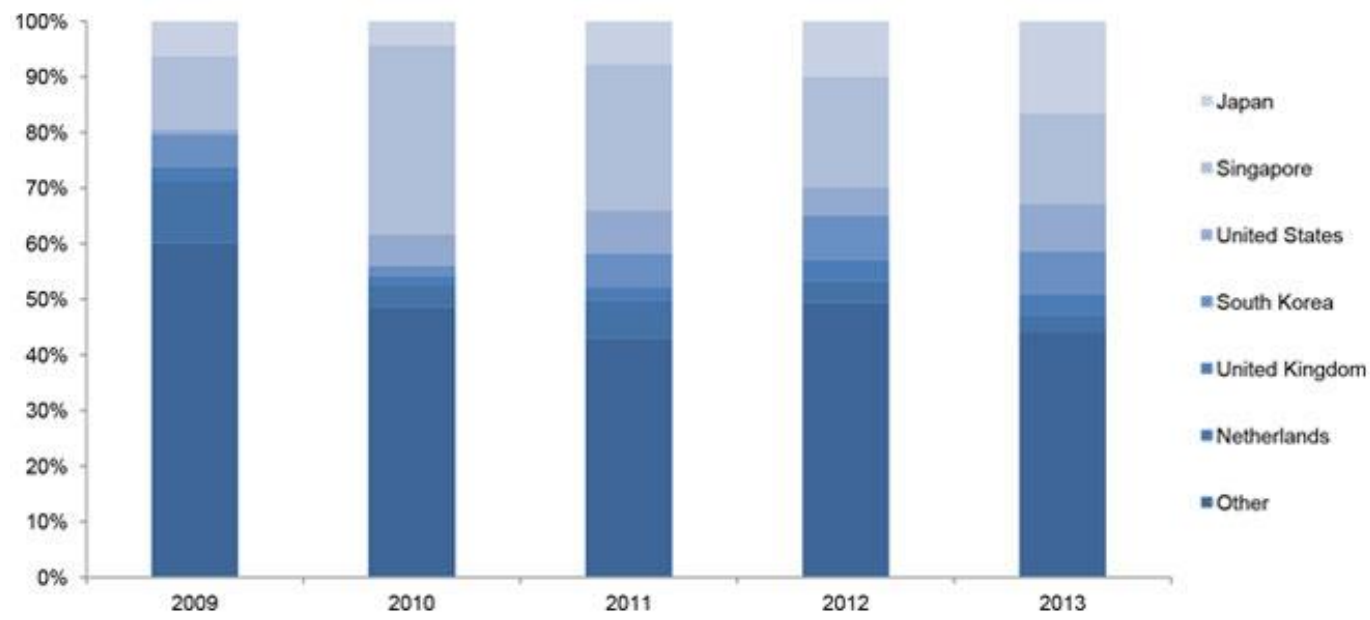

Source: Indonesia Investment Coordinating Board (BKPM)

The above chart 3 explains about the major foreign investors to Indonesia

\section{Impact Of FDI In Indonesia:}

The developing countries highly rely on the inward FDI as a source of assistance for their growth and development but at the same time how far this policy will be effective is a question mark.

The gross fixed capital formation in Indonesia is relatively small when compared to the contribution made by FDI to other ASEAN counties. FDI hashelped to create jobs, which in turn boostedproductivitygrowth andimprovedaccess to the global market. Competition for FDI in Asia isbecoming intense, among ASEAN member countries as well as with China and India.For Japan and Korea, for example,the share of FDI flowing to Indonesia has decreasedvis-à-vis other Asian destinations.FDI in the labour-intensive manufacturing sector has created jobs and contributed to theincreasing share of manufacturing in exports.

\section{Conclusion:}

FDI in Indonesia has indeed helped the country to improve the economy with its investment in small projects and by mostly by means of manufacturing sector which provides maximum employment. But at the same time it needs to concentrate on more capital intensive projects which helps them to export expansion rather than import substitution. The recent shift of FDI projects to capital-intensive sectors, such as mining,and services may not be equally advantageous interms of employment. The challenge for Indonesia now is to improve further its policyframework to attract new foreign investment which can generate more and better jobs, upgrade the industrial and export structure, and improve competitiveness.

\section{References:}

[1]. http://www.tradingeconomics.com/indonesia/foreign-direct-investment-net-inflows-percent-of-gdp-wb-data.html

[2]. http://www.thejakartapost.com/news/2013/01/16/we-should-gain-more-fdi.html

[3]. http://en.wikipedia.org/wiki/Indonesia

[4]. Indonesia Investment Coordinating board

[5]. "Improving Indonesia's Investment Climate" byMisuzuOtsuka, Stephen ThomsenandAndrea Goldstein, in Investment Insights, Feb 2011, Issue 1 